Instructions for authors, subscriptions and further details:

http://rise.hipatiapress.com

\title{
Family Cultural Activities and Educational Expectations of Day High School Students
}

Gerasimos S. Koustourakis $^{1}$

Georgia Spiliopoulou ${ }^{1}$

Anna Asimaki ${ }^{1}$

Konstantinos Lavidas ${ }^{1}$

1) University of Patras, Greece

Date of publication: February $25^{\text {th }}, 2020$

Edition period: February 2020-June 2020

To cite this article: Koustourakis, G.S., Spiliopoulou, G., Asimaki, A. \& Lavidas, K. (2020). Family Cultural Activities and Educational Expectations of Day High School Students, International Journal of Sociology of Education, 9(1), 93-119. doi: 10.17583/rise.2020.4715

To link this article: http://dx.doi.org/10.17583/rise.2020.4715

\section{PLEASE SCROLL DOWN FOR ARTICLE}

The terms and conditions of use are related to the Open Journal System and to Creative Commons Attribution License (CC-BY) 


\section{Family Cultural Activities and Educational Expectations of Day High School Students}

Gerasimos S. Koustourakis

University of Patras

Anna Asimaki

University of Patras
Georgia Spiliopoulou

University of Patras

Konstantinos Lavidas

University of Patras

(Received: 24 September 2019; Accepted: 5 January 2020; Published: 25 February 2020)

\section{Abstract}

This paper, which uses the concepts of 'cultural capital' and 'practice' from Pierre Bourdieu's theory, presents the family cultural activities that Day High School students in Greece adopt in their everyday life and which contribute to shaping their cultural capital. Moreover, an attempt is also made to investigate the role played by the family cultural activities that students adopt, in shaping their expectations concerning their educational future. In this cross-sectional research the sample consists of 1430 2nd grade Day High School students, who attended High School during the school year 2017-2018, and the research data were collected using a questionnaire. The research results showed that the students in the sample tend to accumulate and integrate into the system of their predispositions a smaller or larger volume of cultural capital, which is a function of the range of family cultural activities they adopt in their everyday lives. In addition, the students' everyday family cultural activities tend to 'organize' the system of their expectations, defining their future educational careers, and orienting them to different educational outlets.

Keywords: family cultural activities, educational expectations, students, Day High Schools 


\section{Actividades Culturales Familiares y Expectativas Educativas de los Estudiantes de Escuelas Secundarias Diurnas}

Gerasimos S. Koustourakis

University of Patras

Anna Asimaki

University of Patras
Georgia Spiliopoulou

University of Patras

Konstantinos Lavidas

University of Patras

(Recibido: 24 Septiembre 2019; Aceptado: 5 Enero 2020; Publicado: 25 Febrero 2020)

\section{Resumen}

Este documento, que utiliza los conceptos de "capital cultural" y "práctica" de la teoría de Pierre Bourdieu, presenta las actividades culturales familiares que los estudiantes de Day High School en Grecia adoptan en su vida cotidiana y que contribuyen a dar forma a su capital cultural. Además, también se intenta investigar el papel desempeñado por las actividades culturales familiares que los estudiantes adoptan, para dar forma a sus expectativas con respecto a su futuro educativo. En esta investigación transversal, la muestra consta de 1430 estudiantes de secundaria de segundo grado, que asistieron a la escuela secundaria durante el año escolar 2017-2018, y los datos de la investigación se recopilaron mediante un cuestionario. Los resultados mostraron que los estudiantes en la muestra tienden a acumular e integrar en el sistema de sus predisposiciones un volumen menor o mayor de capital cultural, que es una función del rango de actividades culturales familiares que adoptan en sus vidas. Además, las actividades culturales familiares cotidianas de los estudiantes tienden a "organizar" el sistema de sus expectativas, definiendo sus futuras carreras educativas y orientándolos a diferentes medios educativos.

Palabras clave: Actividades culturales familiares, expectativas educativas, estudiantes, escuelas secundarias diurnas 
umerous empirical sociological studies have placed the central theme of Pierre Bourdieu's theory of cultural reproduction at the heart of their investigation; namely, that a family's cultural capital has a positive and immediate impact on the educational success of its children. In particular, they highlight the impact of different measurements of cultural capital, such as parents' reading habits, as well as their participation in the 'fine arts', on the children's educational success. In fact, the conceptualization of cultural capital in the context of these studies is mainly linked to the most prestigious practices, such as attending an opera and listening to classical music (Crook, 1997; De Graaf, De Graaf, \& Kraaykamp, 2000; DiMaggio, 1982; DiMaggio \& Mohr, 1985; Dumais, 2002; Farkas, Grobe, Sheehan, \& Shuan, 1990; Kalmijn \& Kraaykamp, 1996; Sullivan, 2001; Van de Werfhorst \& Hofstede, 2007).

There are also sociological studies that reveal the impact of cultural capital and habitus on educational success, as well as on young people's educational and occupational choices in relation to their social class of origin, confirming Pierre Bourdieu's theory of cultural reproduction (Davies, Qiu, \& Davies, 2014; Kaufman \& Gabler, 2004; Mullen, 2009; Noble \& Davies, 2009; Sianou-Kyrgiou, 2006; Sianou-Kyrgiou, 2010; SianouKyrgiou \& Tsiplakides, 2009, 2011; Symeou, 2007; Thompson, 2009; Wakeling, 2005; Waters \& Brooks, 2010).

In the context of a review of scientific literature, it is noted that the issue of young people's educational expectations in relation to socio-economic and educational factors of influence, such as the nationality and the educational level of parents, has garnered interest in a large number of scientific papers (see: Broc, 2018; Goyette \& Xie, 1999; Koustourakis, Asimaki, \& Spiliopoulou, 2016; Manganelli Rattazzi \& Capozza, 1995; Marjoribanks, 2003; Minello, 2014; Moussa-Inaty \& De La Vega, 2013; Pac \& Martínez, 2018; Pérez \& Requena, 2019).

Scientific papers exploring the cultural practices that students' families adopt in relation to factors such as the social origin and the educational level of students' parents, have been the subject of limited investigation (see: Koustourakis, Asimaki, \& Spiliopoulou, 2018; Thanos \& Tolios, 2013, 2015; Tolios \& Thanos, 2015). The present paper attempts to cover the research gap found in scientific literature using the concept of 'practice' from Pierre Bourdieu's theory in order to highlight the family cultural 


\section{Koustourakis et al. - Day High School Students}

activities that Day High School students in Greece adopt in their everyday lives, which contribute to the formation and integration of cultural capital into the system of their predispositions (habitus). Furthermore, in the context of the present study, an attempt is made to investigate the role played by the family cultural activities that Day High School students in Greece adopt in the formation of their expectations concerning their educational future.

\section{Theoretical Notes}

In the present paper we will use the concepts of 'cultural capital' and 'practice' from the theory of Pierre Bourdieu.

According to Bourdieu (1986), cultural capital refers to the estimated cultural sources that contribute to maintaining or improving a particular type of the individual's social status (Kim, 2011, p. 111). Cultural capital could be defined as 'the accumulated abilities and capabilities of the family to cultivate the most appreciated social knowledge, sensitivities, modes of expression and action'. It is a 'corpus de savoir, de savoir-faire and mainly de savoir-dire', which reflects attitudes, knowledge and skills in relation to the individuals' social origin (Chauviré \& Fontaine, 2003, p. 12; Lamnias, 2001, p. 157).

Bourdieu (1986, 1994) recognizes three forms of cultural capital: the 'embodied', the 'objectified' and the 'institutionalized' in the form of educational titles.

'Embodied' cultural capital could be defined as the 'durable, transposable predispositions' of the mind and body that direct the individual's actions. Its acquisition is influenced by its primary mode of implantation within the immediate family environment. Cultural capital in its 'embodied' state, which is acquired through a durable process of engraving and incorporation, requires time in order to be invested by the social subject and constitutes 'a have that became a be' (Accardo, 1983, p. 88; Bourdieu, 1994, pp. 77-78).

Cultural capital in its 'objectified' state is associated with the possession of cultural goods and a set of attributes that are defined in relation to the 'embodied' cultural capital. 'Objectified' cultural capital is transmissible in its materiality and the visible cultural goods it includes can be, for example, books and bookcases (Bourdieu, 1994, p. 81; Kraaykamp \& Eijck, 2010, p. 211). 
The 'institutionalized' form of cultural capital refers to the cultural capital that the education system guarantees through the qualifications granted to the subjects of learning (Bourdieu, 1986, p. 248; Lamnias, 2001, p. 158; Levitas, 2004, p. 51; Santasombat, 2004, p. 106).

The concept of practice explains how the objective world and subjective interpretations are united in social action (Vaara \& Whittington, 2012, p. 288). It is the 'ontological coupling' between objective and subjective structures (Robbins, 2008, p. 44), structures and hexis (Bourdieu, 2006, p. 88). The cognitive structures that enable individuals to acknowledge the social world in a practical way are 'internalized' social structures. The practical way of acknowledging the social world activates historical 'schemes' of perception, defining the actions of social subjects (Bourdieu, 2002, p. 495). In this sense, the individuals' actions are placed in the dialectic relationship of 'objectified' history and 'embodied' history, which takes the form of 'systems of durable and transposable predispositions'. This system of predispositions channels into the social agents modes of perception, preference, thought and action, which function as bodies of 'organizing principles', which tend to shape their expectations and practices (Asimaki \& Koustourakis, 2014, p. 123; Bourdieu, 2006, pp. 88-91).

In the context of this study, we attempt to explore the family cultural activities that Day High School students in Greece adopt in their everyday lives, defined by the 'schemes' of perception and thought that students have incorporated into the system of their predispositions, and the role they play in shaping their expectations concerning their educational future (Bourdieu, 2000, 2006).

\section{Research Questions - Methodology}

In this paper we attempt to answer the following research questions:

- Through which family activities is the cultural capital of Day General and Vocational High School students in Greece shaped?

- What is the role of family cultural activities in shaping the educational expectations of Day High School students in Greece? 


\section{Research Tool}

We used cross-sectional research, collecting data at one point in time measuring current attitudes and practices, that is, family cultural activities and educational expectations of Day High School students in Greece (Creswell, 2011). The present study was conducted during the school year 2017-2018, with the administration of a questionnaire to second grade students at 34 Day General and Vocational High Schools in the Educational Region of Western Greece. We chose to investigate 2nd grade High School students, since it is these students that choose school subjects according to their preferences and interests, thus forming an initial educational orientation. In fact, the choices made by the 2 nd grade High School students appear to have a decisive impact on the formation of their expectations concerning their educational future, including whether or not they attend 3rd grade of High School, and their subsequent educational path.

The questionnaire that we drew up for the present research is composed of two parts. The first part includes questions concerning the demographic data of the students and their parents. The second part includes questions which explore the family cultural activities that students adopt in their everyday life using the following 'indicators' derived from Pierre Bourdieu's theoretical scheme regarding the concept of 'practice' (Bourdieu, 2002, 2006): 'Visiting museums', 'Visiting archaeological sites', 'Visiting galleries', 'Going to the theatre', 'Going to bookshops', 'Going to libraries', 'Attending the opera', 'Trips to areas of Greece' and 'Travelling abroad'. The second part of the questionnaire includes questions that attempt to highlight students' expectations for their educational future, defined, in particular, by their expectation concerning choosing an Orientation Group and a Scientific Field in the 3rd Grade of General High School, their expectation concerning choosing a Specialization in the 3rd Grade of Vocational High School, their expectation concerning choosing an education path after the second grade of High School and their expectation concerning choosing a tertiary education Department/School.

The questionnaire was piloted with ten 2 nd grade students at a Day General High School and seven 2nd grade students at a Day Vocational High School, who were then excluded from the research sample. The pilot investigation did not reveal issues that affect the feasibility of this research. 
In the discussion that followed, the students questioned did not report that any parts of the questions were unintelligible (Bryman, 2017; Cohen, Manion, \& Morrison, 2008).

\section{Sample}

We used 'cluster sampling' for the collection of data from the questionnaires. Clusters, in the present research, are the Day General and Vocational High Schools in Greece (Bryman, 2017; Cohen et al., 2008; Creswell, 2011). The research sample includes 1430 second grade students from 34 Day General and Vocational High Schools in Greece. The students participated voluntarily in the research, and their parents' signed consent had previously been secured (Bryman, 2017; Creswell, 2011). As far as the gender distribution of the students is concerned, $51.5 \%$ (736 subjects) of the students are boys and 48.5\% (694 subjects) of the students are girls.

\section{Data Analysis}

We used the cluster analysis (Sharma, 1996) to define groups of students based on the cultural activities they adopt in their everyday lives. The cluster analysis could identify groups from the data based on small within-group and large between-group variance. As discriminant variables for this group, we used the following variables: 'Visiting museums', 'Visiting archaeological sites', 'Visiting galleries', 'Going to the theatre', 'Going to bookshops', 'Going to libraries', 'Attending the opera', 'Trips to areas of Greece' and 'Travelling abroad'. For the determination of clusters or groups, 30 different markers were calculated as described in the R Package analysis (R Core Team, 2018) NbClust (Charrad, Ghazzali, Boiteau, \& Niknafs, 2014). Grouping of students was carried out with hierarchical clustering (Sharma, 1996). The Euclidean distance, which increases the significance of long distances, has been calculated to place the subjects into two groups, while reducing the significance of short distances. In addition, the Ward method was used to distinguish student groups. This method uses F (F value) to maximize the significance of differences between clusters (Charrad et al., 2014; Sharma, 1996). 


\section{Presentation and Analysis of Data}

\section{Cluster Analysis}

For the cluster analysis, the following discriminant variables were used: 'Visiting museums' (Min=1, $\mathrm{Max}=5, \quad \mathrm{M}=1.8, \quad \mathrm{SD}=1.0)$, 'Visiting archaeological sites' ( $\mathrm{Min}=1, \mathrm{Max}=5, \mathrm{M}=1.8, \mathrm{SD}=1.0$ ), 'Visiting galleries' ( $\mathrm{Min}=1, \mathrm{Max}=5, \mathrm{M}=1.2, \mathrm{SD}=0.6$ ), 'Going to the theatre' $(\mathrm{Min}=1$, $\mathrm{Max}=5$, $\mathrm{M}=1.7, \mathrm{SD}=1.0$ ), 'Going to bookshops' ( $\mathrm{Min}=1, \mathrm{Max}=5, \mathrm{M}=2.4, \mathrm{SD}=1.1$ ), 'Going to libraries' (Min=1, Max=5, M=1.3, SD=0.8), 'Trips to areas of Greece' (Min=1, Max=5, M=3.0, SD=1.2) and 'Travelling abroad' (Min=1, $\mathrm{Max}=5, \mathrm{M}=1.4, \mathrm{SD}=0.9)$. The 'attending the opera' variable was not used in the analysis of this paper. This was because it showed almost zero fluctuation ( $\mathrm{Min}=1, \mathrm{Max}=5, \mathrm{M}=1.0, \mathrm{SD}=0.2$ ). In fact, the overwhelming majority of students $(97.5 \%)$ replied to the corresponding question that they had not attended this particular 'high brow' cultural activity ever (Bourdieu, 2002).

Initially, we determined the number of student clusters. According to the majority of Indices and in particular the indices KL, CH, DB, Silhouette, Ratkowsky, McClain, SDindex (Charrad et al., 2014), the best number of clusters is 2. In terms of the expectation regarding the choice of an Orientation Group and a Scientific Field in the 3rd grade of General High School, the hierarchical classification indicated: 293 (27.0\%) second grade General High School students in the first group and 793 (73.0\%) second grade General High School students in the second group. Regarding the expectation concerning a Specialization choice in the 3rd grade of Vocational High School, the hierarchical classification indicated: 34 (10.0\%) second grade Vocational High School students in the first group and 310 (90.0\%) second grade Vocational High School students in the second group. Finally, in terms of the expectation concerning an educational path choice after the second grade of High School and the expectation concerning a Department/School choice, the hierarchical classification indicated: 327 (22.9\%) second grade High School students (General/Vocational) in the first group and 1103 (77.1\%) second grade High School students (General/Vocational) in the second group. 
Table 1 presents Descriptive Statistics data (minimum value, maximum value, mean and standard deviation) concerning the composition of the two groups based on the discriminant variables: 'Visiting museums', 'Visiting archaeological sites', 'Visiting galleries', 'Going to the theatre', 'Going to bookshops', 'Going to libraries', 'Trips to areas of Greece' and 'Travelling abroad', used in the cluster analysis. The Eta square, shown in Table 1, indicates that the variance of the discriminant variables is explained to a very satisfactory level by the two groups (Tabachnick \& Fidell, 2007).

Table 1

Descriptive Statistics data on family cultural activities adopted by the two groups of Day High School students in the sample

\begin{tabular}{|c|c|c|c|c|c|c|c|c|c|}
\hline & \multicolumn{4}{|c|}{ 1st Cluster } & \multicolumn{5}{|c|}{ 2nd Cluster } \\
\hline & Min & Max & $\mathrm{M}^{*}$ & SD & Min & Max & $\mathrm{M}^{*}$ & SD & $\begin{array}{l}\text { Eta } \\
\text { square }\end{array}$ \\
\hline Visiting museums & 1 & 5 & 3.2 & .9 & 1 & 4 & 1.4 & 6 & 0.571 \\
\hline $\begin{array}{l}\text { Visiting } \\
\text { archaeological sites }\end{array}$ & 1 & 5 & 3.2 & .9 & 1 & 4 & 1.4 & .6 & 0.539 \\
\hline Visiting galleries & 1 & 5 & 1.8 & 1.0 & 1 & 2 & 1.0 & .1 & 0.315 \\
\hline Going to the theatre & 1 & 5 & 3.1 & 1.0 & 1 & 5 & 1.3 & .5 & 0.559 \\
\hline Going to bookshops & 1 & 5 & 3.7 & .9 & 1 & 5 & 2.0 & .7 & 0.453 \\
\hline Going to libraries & 1 & 5 & 2.3 & 1.1 & 1 & 4 & 1.0 & .2 & 0.47 \\
\hline $\begin{array}{l}\text { Trips to areas of } \\
\text { Greece }\end{array}$ & 2 & 5 & 4.3 & .8 & 1 & 5 & 2.6 & .9 & 0.385 \\
\hline Travelling abroad & 1 & 5 & 2.2 & 1.4 & 1 & 4 & 1.1 & .4 & 0.298 \\
\hline
\end{tabular}

*The $\mathrm{M}$ represents means for all students within clusters.

Descriptive Statistics data in Table 1 indicate that the two groups of students have been formed on the basis of the smallest and highest degree of adoption of family cultural activities in their everyday lives. Thus, the first group of students adopts to a greater extent, as against the second group of students, visits to museums $(\mathrm{M}=3.2, \quad \mathrm{SD}=0.9$ and $\mathrm{M}=1.4, \quad \mathrm{SD}=0.6$ respectively), visits to archaeological sites $(\mathrm{M}=3.2, \mathrm{SD}=0.9$ and $\mathrm{M}=1.4$, $\mathrm{SD}=0.6$ respectively), visits to galleries $(\mathrm{M}=1.8, \mathrm{SD}=1.0$ and $\mathrm{M}=1.0$, $\mathrm{SD}=0.1$ respectively), visits to theatres $(\mathrm{M}=3.1, \mathrm{SD}=1.0$ and $\mathrm{M}=1.3, \mathrm{SD}=0.5$ respectively), visits to bookshops $(\mathrm{M}=3.7, \mathrm{SD}=0.9$ and $\mathrm{M}=2.0, \mathrm{SD}=0.7$ respectively), visits to libraries $(\mathrm{M}=2.3, \mathrm{SD}=1.1$ and $\mathrm{M}=1.0, \mathrm{SD}=0.2$ 


\section{Koustourakis et al. - Day High School Students}

respectively), trips to areas of Greece $(\mathrm{M}=4.3, \mathrm{SD}=0.8$ and $\mathrm{M}=2.6, \mathrm{SD}=0.9$ respectively) and travelling abroad $(\mathrm{M}=2.2, \mathrm{SD}=1.4$ and $\mathrm{M}=1.1, \mathrm{SD}=0.4$ respectively).

It could be argued that through the implementation of the specific cultural activities, a wide range of cultural representations and experiences can be added to the 'embodied' cognitive structures of the students in the sample. This can contribute to the restructuring of the system of the student's predispositions and to 'orchestrate' the system of their expectations/choices (Bourdieu, 2002, 2006; Bourdieu \& Wacquant, 1992; Sirna, Tinning, \& Rossi, 2010).

\section{Students' Educational Expectations}

Table 2 shows the distribution of the 2nd grade General High School students in the sample regarding their expectations of an Orientation Group choice in the 3rd grade of General High School according to the degree of adoption of family cultural activities.

Table 2

Expectation of an Orientation Group choice by 3rd grade General High School students, according to the degree of adoption of family cultural activities

\begin{tabular}{ccc}
$\begin{array}{c}\text { Expectation of an Orientation Group } \\
\text { choice by 3rd grade General High } \\
\text { School students }\end{array}$ & $\begin{array}{c}\text { A large degree of adoption of } \\
\text { family cultural activities by } \\
\text { the 1st group of students }\end{array}$ & $\begin{array}{c}\text { A small degree of adoption } \\
\text { of family cultural activities } \\
\text { by the 2nd group of students }\end{array}$ \\
\hline $\begin{array}{c}\text { Humanities Orientation Group } \\
\text { Sciences Orientation Group }\end{array}$ & $102(34.8)$ & $336(42.4)$ \\
$\begin{array}{c}\text { Economic and Computer Studies } \\
\text { Orientation Group } \\
\text { Sum total }\end{array}$ & $31(100(54.6)$ & $300(37.8)$ \\
& $293(100.0)^{*}$ & $157(19.8)$ \\
\end{tabular}

*Number and (percentage) of the sum total of the 1st group of 2nd grade General High School students in the sample.

** Number and (percentage) of the sum total of the 2nd group of 2nd grade General High School students in the sample.

The statistical elaboration of the research data in Table 2 revealed the existence of a statistically significant relationship between the 'expectation of an Orientation Group choice by the students in the third grade of General High School' and the 'cultural activities' adopted by the students' families 
$\left(\chi^{2}=27.749, \mathrm{df}=2, \mathrm{p}=0.001\right.$, Cramer's $\left.\mathrm{V}=0.160\right)$. The data in Table 2 show that the 2nd group of students expect to choose the Humanities Orientation Group (336 subjects, 42.4\%) and the Economic and Computer Studies Orientation Group (157 subjects, 19.8\%) in the third grade of General High School at a higher rate compared to the students in the 1st group (102 subjects, $34.8 \%$ and 31 subjects, $10.6 \%$ respectively). On the other hand, the 1st group of students expects to choose the Sciences Orientation Group (160 subjects, 54.6\%) in the third grade of General High School at a higher rate when compared to the students in the 2nd group (300 subjects, 37.8\%).

Table 3 gives the distribution of the 2nd grade General High School students in the sample as regards their expectations of a Scientific Field choice in the 3rd grade of General High School according to the degree of adoption of family cultural activities.

Table 3

Expectation of a Scientific Field choice by 3rd grade General High School students, according to the degree of adoption of family cultural activities

Expectation of a Scientific Field choice by 3rd grade General High School students

1st Scientific Field: Humanities,

Law and Social Sciences

2nd Scientific Field: Positive and

Technological Sciences

3rd Scientific Field: Health and Life Sciences

4th Scientific Field: Sciences of

Economics and Informatics

1st or 3rd Scientific Field

2nd or 3rd Scientific Field

Sum total
A large degree of adoption of family cultural activities by the 1st group of students 96 (32.8) $74(25.3)$ $69(23.5)$ 31 (10.6) $293(100.0)^{*}$
A small degree of adoption of family cultural activities by the 2 nd group of students 303 (38.2) $189(23.8)$ $79(10.0)$ 157 (19.8)

$793(100.0)^{* * *}$

\footnotetext{
*Number and (percentage) of the sum total of the 1st group of 2nd grade General High School students in the sample.

** Number and (percentage) of the sum total of the 2nd group of 2nd grade General High School students in the sample.
}

The statistical analysis of the research data in Table 4 revealed the existence of a statistically significant relationship between the 'expectation of a Scientific Field choice by 3rd grade General High School students' and 


\section{Koustourakis et al. - Day High School Students}

the 'family cultural activities adopted by the students' $\left(\chi^{2}=44.195, \mathrm{df}=5\right.$, $\mathrm{p}=0.001$, Cramer's $\mathrm{V}=0.202$ ). The data in Table 3 show that the 2nd group of students expect to choose the 1st Scientific Field, namely the Humanities, Law and Social Sciences (303 subjects, 38.2\%) more than the 1st group of students (96 subjects, 32.8\%). On the other hand, the expectation that they will choose the 3rd scientific field, namely Health and Life Sciences, is expressed at a higher rate by the first group of students (69 subjects, 23.5\%) compared to the 2 nd group of students ( 79 subjects, $10.0 \%$ ).

Table 4 shows the distribution of the 2nd grade Vocational High School students in the sample with regard to their expectations of a Specialization choice in the 3rd grade of Vocational High School according to the degree of adoption of family cultural activities. 


\section{RISE - International Journal of Sociology of Education, 9(1) 105}

\section{Table 4}

\section{Expectation of a Specialization choice by 3rd grade Vocational High School} students, according to the degree of adoption of family cultural activities

Expectation of a Specialization choice by 3rd grade Vocational High School students

Food and Drink Technology Technician

Plant Production Technician

Animal Production Technician

Administrator and Financial Officer

Tourism Industry Employee

Marketing and Advertising Employee

Electronics and Computing Systems, Installations, Networks and

Telecommunications Technician

Electrical Systems, Installations and Networks Technician

Mechanical Engineering and Construction Engineer

Vehicle Technician

Ventilation and Air Conditioning Cooling Technician

Thermal and Hydraulic Installations and Technology of Oil and Natural Gas Technician Computer Engineer and Computer Networks Technician

IT Application Technician

Merchant Navy Captain

Merchant Navy Engineer

Nurse's Assistant

Nursing Home Assistant

Beautician

Physiotherapist's Assistant

Hairdressing
A large degree of adoption of family cultural activities by the 1 st group of students
A small degree of adoption of family cultural activities by the 2nd group of students

$\begin{array}{lc}3(8.8) & 12(3.9) \\ 2(5.9) & 8(2.6)\end{array}$

$1(2.9)$

7 (20.6)

47 (15.2)

$2(5.9)$

$14(4.5)$

$0(0.0)$

$1(0.3)$

$0(0.0)$

$0(0.0)$

$28(9.0)$

$2(5.9)$

$20(6.5)$

$1(2.9)$

54 (17.4)

$1(2.9)$

7 (2.3)

$1(2.9)$

4 (11.8)

$1(2.9)$

$20(6.5)$

$0(0.0)$

$6(1.9)$

$1(2.9)$

$13(4.2)$

4 (11.8)

1 (2.9)

$12(3.9)$

$1(2.9)$

$0(0.0)$

$2(0.6)$

Sum total

$34(100.0)^{*}$

$310(100.0)^{* *}$

\footnotetext{
$*$ Number and (percentage) of the sum total of the 1st group of 2nd grade Vocational High School students in the sample.

** Number and (percentage) of the sum total of the 2nd group of 2nd grade Vocational High School students in the sample.
} 
From the statistical elaboration of the research data in Table 4, no statistically significant relationship emerged between the 'expectation of a Specialization choice by 3rd grade Vocational High School students' and the 'family cultural activities adopted by the students' $\left(\chi^{2}=28.523, \mathrm{df}=21\right.$, $\mathrm{p}=0.126$ ). The data in Table 4 show that the expectations of a Specialization choice by 3rd grade Vocational High School students do not reveal significant differences between the two groups based on cluster analysis. It could therefore be argued that the factor of Vocational High School attendance appears to be decisive in shaping, in almost an undifferentiated way, the expectations of the students concerning their choice of a Specialization in the 3rd grade of Vocational High School. That is, the specific factor greatly homogenizes the expectations of the Vocational High School students in the sample regardless of the kind of cultural activities their families adopt (Bourdieu, 2000, 2006).

Table 5 presents the distribution of the 2nd grade High School students (General/Vocational) in the sample concerning their expectations of an educational path choice after the second grade of High School according to the degree of adoption of family cultural activities. 
Table 5

Students' expectation regarding an educational path choice after the second grade of High School according to the degree of adoption of family cultural activities

Expectation regarding an educational

path choice by the students after the second grade of High School
A large degree of adoption of family cultural activities by the 1st group of students

$4(1.2)$

$1(0.3)$

$23(7.0)$

$62(19.0)$

$199(60.9)$

38 (11.6) $327(100.0)^{*}$
A small degree of adoption of family cultural activities by the 2nd group of students

Finish High School and then find a job Institute of Vocational Training

Finish High School and then

study at a Technological Educational Institute

Finish High School and then study at University

Finish High School, study at

University and then pursue postgraduate/ $\mathrm{PhD}$ studies

Finish High School and then pursue studies related to the Army and Security Corps

Sum total

$108(9.8)$

$52(4.7)$

$187(17.0)$

$260(23.6)$

$307(27.8)$

$189(17.1)$

$1103(100.0)^{* *}$

* Number and (percentage) of the sum total of the 1st group of 2nd grade High School students (General/Vocational) in the sample.

** Number and (percentage) of the sum total of the 2nd group of 2nd grade High School students (General/Vocational) in the sample.

The statistical analysis of the research data in Table 5 revealed the existence of a statistically significant relationship between the 'expectation of an educational path choice after the second grade of High School' and the 'family cultural activities adopted by the students' $\left(\chi^{2}=138.718, \mathrm{df}=5\right.$, $\mathrm{p}=0.001$, Cramer's V=0.311). As shown in Table 5, the 1st group of students tends to express higher educational expectations concerning their educational path after the second grade of High School, compared to the 2nd group of students. In particular, a higher percentage of the 1st group of students (199 subjects, 60.9\%), compared to the 2nd group of students (307 subjects, 27.8\%), expects to study at University and then pursue postgraduate/PhD studies. On the other hand, a higher percentage of the 2nd group of students (187 subjects, 17.0\%) expects to finish high school and study at a Technological Educational Institute compared to the 1st group of students (23 subjects, $7.0 \%$ ). 
In this case, it could be argued that the greater degree of acquaintance of students with cultural 'practices' strengthens their cultural capital in the context of the accumulation of an enlarged body of cultural stimuli and images. This seems to contribute to the formation of a system of higher educational expectations regarding their future educational careers (Bourdieu, 1994, 2000, 2006; Bourdieu \& Passeron, 1996).

Table 6 presents the distribution of the 2nd grade High School students (General/Vocational) in the sample regarding their expectations of a Department/School choice according to the degree of adoption of family cultural activities. 
Table 6

Expectation regarding a Department/School choice of the 2nd grade High School students according to the degree of adoption of family cultural activities

\begin{tabular}{|c|c|c|}
\hline $\begin{array}{l}\text { Expectation regarding a Department/School choice by } \\
\text { the } 2 \text { nd grade High School students }\end{array}$ & $\begin{array}{l}\text { A large degree of } \\
\text { adoption of family } \\
\text { cultural activities } \\
\text { by the } 1 \text { st group } \\
\text { of students }\end{array}$ & $\begin{array}{c}\text { A small degree of } \\
\text { adoption of family } \\
\text { cultural activities by } \\
\text { the 2nd group of } \\
\text { students }\end{array}$ \\
\hline I do not want to study in any Department/School & $4(1.2)$ & $108(9.8)$ \\
\hline Departments of Health and Life Sciences (University) & $66(20.2)$ & $76(6.9)$ \\
\hline Polytechnic Departments (University) & $51(15.6)$ & $103(9.3)$ \\
\hline Science Departments (University) & $23(7.0)$ & $53(4.8)$ \\
\hline Law Departments (University) & $24(7.3)$ & $37(3.4)$ \\
\hline Departments of Pedagogical Studies (University) & $26(8.0)$ & $104(9.4)$ \\
\hline Departments of Economic Sciences (University) & $14(4.3)$ & $73(6.6)$ \\
\hline School of Philosophy Departments (University) & $46(14.1)$ & $101(9.2)$ \\
\hline Departments of Sociology (University) & $11(3.4)$ & $20(1.8)$ \\
\hline $\begin{array}{l}\text { Departments/Schools related to the Army and } \\
\text { Security Corps }\end{array}$ & $38(11.6)$ & 189 (17.1) \\
\hline $\begin{array}{l}\text { Departments of Health and Life Sciences } \\
\text { (Technological Educational Institute) }\end{array}$ & $5(1.5)$ & $39(3.5)$ \\
\hline $\begin{array}{l}\text { Technological Departments (Technological } \\
\text { Educational Institute) }\end{array}$ & $8(2.4)$ & $89(8.1)$ \\
\hline $\begin{array}{c}\text { Departments of Economics (Technological } \\
\text { Educational Institute) }\end{array}$ & $8(2.4)$ & $51(4.6)$ \\
\hline $\begin{array}{l}\text { Preschool Teaching Departments (Technological } \\
\text { Educational Institute) }\end{array}$ & $2(0.6)$ & $8(0.7)$ \\
\hline Technical Schools (Institute of Vocational Training) & $1(0.3)$ & $52(4.7)$ \\
\hline Sum total & $327(100.0)^{*}$ & $1103(100.0)^{* *}$ \\
\hline
\end{tabular}

* Number and (percentage) of the sum total of the 1st group of 2nd grade High School students (General/Vocational) in the sample.

** Number and (percentage) of the sum total of the 2nd group of 2nd grade High School students (General/Vocational) in the sample.

The statistical elaboration of the research material related to the data in Table 6 revealed the existence of a statistically significant relationship between the 'expectation regarding a Department/School choice' and the 'family cultural activities adopted by the students' $\left(\chi^{2}=137.088, \mathrm{df}=14\right.$, $\mathrm{p}=0.001$, Cramer's $\mathrm{V}=0.310$ ). As the data in Table 6 reveal, a higher percentage of the expectations of the 1st group of students are oriented 


\section{Koustourakis et al. - Day High School Students}

towards university studies in the School of Health and Life Sciences (66 subjects, 20.2\%), the Polytechnic School (51 subjects, 15.6\%) and the School of Philosophy (46 subjects, 14.1\%), which tend to lead to occupations with high prestige in Greece, such as the medical profession, compared to the expectations of the 2 nd group of students (School of Health and Life Sciences: 76 subjects, 6.9\%, Polytechnic School: 103 subjects, 9.3\% and School of Philosophy: 101 subjects, 9.2\% respectively). Moreover, it is worth noting that a higher number of the 2 nd group of students (108 subjects, 9.8\%) state that they do not wish to study in any Department/School compared to the 1st group of students (4 subjects, 1.2\%). It could therefore be argued that the (higher or lower) levels of integration of cultural capital in the High School students' system of predispositions tend to dictate their educational aspirations regarding, in particular, their expectation to make a University choice for the continuation of their studies (Bourdieu, 2000, 2006).

\section{Discussion and Conclusions}

From the elaboration and analysis of the research data, the following findings emerge:

As regards the answer to the first research question, the cultural capital of the Day General and Vocational High School students in the sample seems to be shaped by adopting a series of family cultural activities that tend to characterize the image of the 'cultivated' person (Bourdieu, 2002, 2006; Bourdieu \& Passeron, 1996; Vryonides, 2009). In particular, it is about adopting the practice of visiting museums, archaeological sites, galleries, theatres, bookshops and libraries, as well as going on trips to areas of Greece and travelling abroad. It could be argued that through the adoption of these cultural activities it is possible to channel a variety of cultural stimuli and images related to Art and Culture into the system of cognitive structures of the students in the sample (Blackledge \& Hunt, 2000; Bourdieu, 2002; Bourdieu \& Passeron, 1996; Lamnias, 2001; Li, 2007; Swingewood, 1998).

The two groups of 2nd grade High School students (General/Vocational) in the sample, as they were composed on the basis of the cluster analysis in the context of this study, are differentiated according to the small or large adoption of family cultural activities. In particular, the first group of students 
in the sample tends to adopt, to a greater extent, the practice of visiting museums, archaeological sites, galleries, theatres, bookshops and libraries, as well as going on trips to areas of Greece and travelling abroad. In this case, the possibility of incorporating and appropriating a body of cultural representations and images into the system of predispositions of the students in the sample, especially those who largely adopt these cultural activities, could be mentioned. This can contribute to the students' integration into an expanded culture offering stimuli of a more 'cultivated' reality (Accardo, 1983; Bourdieu, 1994; Bourdieu \& Passeron, 1996; Koustourakis et al., 2018; Wacquant, 2008, 2011).

As far as the answer to the second research question is concerned, the adoption of family cultural activities by the Day General and Vocational High School students in the sample tends to play a role - to a greater or lesser extent- in their educational aspirations. In particular, the High School students (General/Vocational) in the sample who adopt to either a certain extent or to a large extent the specific cultural activities tend to express differentiated educational expectations, including the expectation of an Orientation Group and a Scientific Field choice in the 3rd grade of General High School, the expectation of an educational path choice after the second grade of High School and the expectation of a Department/School choice. It is worth noting, however, that the expectation of a choice of Specialization in the 3rd grade of Vocational High School by the 2nd grade Vocational High School students in the sample does not show significant differences between the two groups.

In particular, it is noted that the 2nd grade General High School students in the sample who adopt the specific cultural activities to only a small extent, expect to a greater degree to choose the Humanities Orientation Group and the Economic and Computer Studies Orientation Group in the 3rd grade of General High School, as compared with the 2nd grade General High School students who adopt them to a large extent. On the other hand, the 2 nd grade General High School students in the sample who adopt them to a large extent express a greater expectation of choosing the Orientation Group of Positive Studies in the 3rd grade of General High School, in comparison with the 2nd grade General High School students who adopt them to a small extent. Also, the 2nd grade General High School students in the sample who adopt the specific cultural 'practices' to a small extent expect to a greater 


\section{Koustourakis et al. - Day High School Students}

degree to choose the 1st Scientific Field in the 3rd grade of General High School, namely the Humanities, Law and Social Sciences, in relation to the 2nd grade General High School students who adopt them to a large extent. On the other hand, the expectation of choosing the 3rd Scientific field, namely Health and Life Sciences, is expressed by a higher percentage of the students who adopt the specific cultural 'practices' to a large extent, compared to the 2nd grade General High School students who adopt them to a small extent.

In addition, the 2nd grade General High School students in the sample, mainly those attending the General High School, who largely adopt the specific cultural activities, tend to express higher educational expectations concerning their educational path after the second grade of High School, compared to the students who adopt them to a small extent. In particular, the expectations of the students in the sample who adopt them to a large extent are oriented more towards University studies in the School of Health and Life Sciences, in the Polytechnic School and in the School of Philosophy, compared to the students who adopt them to a small extent. Findings of related studies reveal the impact of cultural capital, expressed through various cultural 'indicators', in the formation of students' high educational expectations/choices (see: Davies et. al., 2014; Koustourakis et al., 2016; Noble \& Davies, 2009; Van de Werfhorst, Sullivan, \& Cheung, 2003), which leads them to a successful educational career (see: Dumais, 2002; Sullivan, 2001). In this sense, it could be argued that the system of high educational expectations of the students in the sample, mainly those who attended the General High School, who largely adopt the specific cultural activities, tends to be dictated by the accumulation, in the system of their predispositions, of a body of cultural stimuli and experiences formed in the context of familiarity with a range of cultural 'practices' (Bourdieu, 2000, 2006; Bourdieu \& Passeron, 1996).

Finally, the research findings lead us to draw the following conclusions:

- The cultural capital of the Day General and Vocational High School students in the sample as it is accumulated and integrated into the system of their predispositions through the adoption of family cultural activities in their everyday lives, and which includes the practice of visiting museums, archaeological sites, galleries, theatres, bookshops and libraries, as well as going on trips to areas 
of Greece and travelling abroad, tends to play a role -to a greater or lesser extent- in shaping their educational expectations. In particular, the larger or smaller volume of accumulated cultural capital tends to dictate the 'schemes' of perception, thought and action of the students in the sample, which, in turn, contribute to the shaping of their differentiated expectations concerning their educational future (Blackledge \& Hunt, 2000; Bourdieu, 1987, 1994, 2002, 2006).

- It could therefore be argued that the (higher or lower) levels of integration of cultural capital into the system of predispositions of the Day General and Vocational High School students in the sample through the adoption of a range of family cultural activities tend to direct the 'repertoire' of their educational expectations, as well as to 'orchestrate' -to a greater or lesser extent- their educational outlets (Accardo, 1983; Bourdieu, 2000, 2002, 2006; Bourdieu \& Passeron, 1996).

The findings of the present study are interesting because they highlight the family cultural activities of the General and Vocational High School students in Greece to a large or small extent and at the same time they reflect the role they play in shaping their expectations concerning their educational future. Similar research on a larger scale in other countries would be of particular interest in terms of the possibilities it would offer for highlighting the family cultural activities adopted by the High school students in the context of the cultural particularities of the country they live in and which may contribute to the shaping of their educational aspirations.

\section{References}

Accardo, A. (1983). Initiation à la Sociology. L' illustrationnisme social. Bordeaux: Le Mascaret.

Asimaki, A., \& Koustourakis, G. (2014). Habitus: An attempt at a thorough analysis of a controversial concept in Pierre Bourdieu's theory of practice. Social Sciences, 3(4), 121-131. doi: 10.11648/j.ss.20140304.13

Blackledge, D., \& Hunt, B. (2000). Sociology of Education. Athens: Metaixmio. 


\section{Koustourakis et al. - Day High School Students}

Bourdieu, P. (1986). The forms of capital. In J.G. Richardson (Ed.), Handbook of theory and research for the sociology of education (pp. 241-258). New York: Greenwood Press.

Bourdieu, P. (1987). Choses dites. Paris: Les Éditions de Minuit.

Bourdieu, P. (1994). Texts of Sociology. Athens: Delfini.

Bourdieu, P. (2000). Practical Reason: On the Theory of Action. Athens: Plethron.

Bourdieu, P. (2002). Distinction. A Social Critique of the Judgment of Taste. Athens: Patakis.

Bourdieu, P. (2006). The sense of practice. Athens: Alexandreia.

Bourdieu, P., \& Passeron, J.-C. (1996). The inheritors: Students and their culture. Athens: Kardamitsas.

Bourdieu, P., \& Wacquant, L. (1992). An invitation to reflexive sociology. Cambridge: Polity Press.

Broc, M. (2018). Academic performance and other psychological, social and family factors in compulsory secondary education students in a multicultural context. International Journal of Sociology of Education, 7(1), 1-23. doi: 10.17583/rise.2018.2846

Bryman, A. (2017). Social research methods. Athens: Gutenberg.

Charrad, M., Ghazzali, N., Boiteau, V., \& Niknafs, A. (2014). NbClust: An $\mathrm{R}$ Package for Determining the Relevant Number of Clusters in a Data Set. Journal of Statistical Software, 61(6), 1-36. doi: 10.18637/jss.v061.i06.

Chauviré, C., \& Fontaine, O. (2003). Le vocabulaire de Bourdieu. Paris: Ellipses.

Cheadle, J. E. (2008). Educational investment, family context, and children's Math and Reading growth from Kindergarten through the third Grade. Sociology of Education, 81(1), 1-31. doi: 10.1177/003804070808100101

Cohen, L., Manion, L., \& Morrison, K. (2008). Research methods in education. Athens: Metaixmio.

Creswell, J. W. (2011). Educational research: Planning, conducting and evaluating quantitative and qualitative research. Athens: Ion.

Crook, C. J. (1997). Cultural practices and socioeconomic attainment: The Australian experience. Westport, CN: Greenwood Press. 
Davies, P., Qiu, T., \& Davies, N. M. (2014). Cultural and human capital, information and higher education choices. Journal of Education Policy, 29(6), 804-825. doi: 10.1080/02680939.2014.891762

De Graaf, N. D., De Graaf, P. M., \& Kraaykamp, G. (2000). Parental cultural capital and educational attainment in the Netherlands: A refinement of the cultural capital perspective. Sociology of Education, 73(2), 92-111. doi:10.2307/2673239

DiMaggio, P. (1982). Cultural capital and school success: The impact of status culture participation on the grades of U.S. high school students. American Sociological Review, 47(2), 189-201. doi: 10.2307/2094962 DiMaggio, P., \& Mohr, J. (1985). Cultural capital, educational attainment, and marital selection. American Journal of Sociology, 90(6), 12311261. doi: $10.1086 / 228209$

Dumais, S. A. (2002). Cultural capital, gender, and school success: The role of habitus. Sociology of Education, 75(1), 44-68. doi: 10.2307/3090253

Farkas, G., Grobe, R. P., Sheehan, D., \& Shuan, Y. (1990). Cultural resources and school success: Gender, ethnicity, and poverty groups within an urban school district. American Sociological Review, 55(1), 127-142. doi: 10.2307/2095708

Goyette, K., \& Xie, Y. (1999). Educational expectations of Asian American youths: Determinants and ethnic differences. Sociology of Education, 72(1), 22-36. doi: 10.2307/2673184

Kalmijn, M., \& Kraaykamp, G. (1996). Race, cultural capital, and schooling: An analysis of trends in the United States. Sociology of Education, 69, 22-34. doi:10.2307/2112721

Kaufman, J., \& Gabler, J. (2004). Cultural capital and the extracurricular activities of girls and boys in the college attainment process. Poetics, 32(2), 145-168. doi: 10.1016/j.poetic.2004.02.001

Kim, J. (2011). Aspiration for global cultural capital in the stratified realm of global higher education: why do Korean students go to US graduate schools? British Journal of Sociology of Education, 32(1), 109-126. doi: 10.1080/01425692.2011.527725

Koustourakis, G., Spiliopoulou, G., \& Asimaki, A. (2016). The influence of a family's cultural capital on the formation of the educational and occupational expectations of native and immigrant primary school 
students. Educational Journal of the University of Patras UNESCO Chair, 3(1), 8-27.

Koustourakis, G., Asimaki, A., \& Spiliopoulou, G. (2018). Cultural activities and the family's 'institutionalised' cultural capital: the case of native and immigrant primary school pupils. Pedagogy, Culture \& Society, 26(3), 397-415. doi: 10.1080/14681366.2017.1412340

Kraaykamp, G., \& Eijck, K. V. (2010). The intergenerational reproduction of cultural capital: a threefold perspective. Social Forces, 89(1), 209231. doi: 10.1353/sof.2010.0087

Lamnias, K. (2001). Sociological theory and education. Athens: Metaixmio. Li, G. (2007). Home environment and second-language acquisition: the importance of family capital. British Journal of Sociology of Education, 28(3), 285-299. doi: 10.1080/01425690701252028

Manganelli Rattazzi, A. M., \& Capozza, D. (1995). The influence of the family on status expectations of Italian adolescents. International Journal of Adolescence and Youth, 5(4), 263-286. doi: 10.1080/02673843.1995.9747771

Marjoribanks, K. (2003). Family background, individual and environmental influences, aspirations and young adults' educational attainment: A follow-up study, Educational Studies, 29(2-3), 233-242. doi: 10.1080/03055690303283

Minello, A. (2014). The educational expectations of Italian children: the role of social interactions with the children of immigrants. International Studies in Sociology of Education, 24(2), 127-147. doi: 10.1080/09620214.2014.896567

Moussa-Inaty, J., \& De La Vega, E. (2013). From their perspective: Parental involvement in the UAE. International Journal of Sociology of Education, 2(3), 292-312. doi: 10.4471/rise.2013.35

Mullen, A. L. (2009). Elite destinations: pathways to attending an Ivy League University. British Journal of Sociology of Education, 30(1), 15-27. doi: 10.1080/01425690802514292

Noble, J., \& Davies, P. (2009). Cultural capital as an explanation of variation in participation in higher education. British Journal of Sociology of Education, 30(5), 591-605. doi: 10.1080/01425690903101098

Pac, D., \& Martínez, C. S. (2018). Family practices in the construction of creative professionals. A biographical perspective. International 
Journal of Sociology of Education, 7(3), 256-277. doi: 10.17583/rise.2018.3631

Pérez, M. Á. L., \& Requena, A. T. (2019). El Capital Cultural como Predictor del Rendimiento Escolar en España. International Journal of Sociology of Education, 8(1), 45-74. doi: 10.17583/rise.2019.3862

$\mathrm{R}$ Core Team (2018). R: A language and environment for statistical computing. $R$ Foundation for Statistical Computing. Vienna, Austria. Retrieved from https://www.R-project.org/

Robbins, D. (2008). Theory of practice. In M. Grenfell (Ed.), Pierre Bourdieu: Key Concepts (pp. 27-40). Stocksfield: Acumen.

Santasombat, Y. (2004). Karen cultural capital and the political economy of symbolic power. Asian Ethnicity, 5(1), 105-120. doi: 10.1080/1463136032000168925

Sharma, S. (1996). Applied multivariate techniques. New York: John Wiley and Sons.

Sianou-Kyrgiou, E. (2006). Education and social inequalities - The transition from Secondary to Higher Education (1997 - 2004). Athens: Metaixmio.

Sianou-Kyrgiou, E. (2010). Stratification in higher education, choice and social inequalities in Greece. Higher Education Quarterly, 64(1), 22-40. doi: 10.1111/j.1468-2273.2009.00427.x

Sianou-Kyrgiou, E., \& Tsiplakides, I. (2009). Choice and social class of medical school students in Greece. British Journal of Sociology of Education, 30(6), 727-740. doi: 10.1080/01425690903235276

Sianou-Kyrgiou, E., \& Tsiplakides, I. (2011). Similar performance, but different choices: social class and higher education choice in Greece. Studies in Higher Education, 36(1), 89-102. doi: 10.1080/03075070903469606

Sirna, K., Tinning, R., \& Rossi, T. (2010). Social processes of health and physical education teachers' identity formation: reproducing and changing culture. British Journal of Sociology of Education, 31(1), 71-84. doi: 10.1080/01425690903385501

Sullivan, A. (2001). Cultural capital and educational attainment. Sociology, 35(4), 893-912. doi: 10.1177/0038038501035004006

Swingewood, A. (1998). Cultural theory and the problem of modernity. New York: St. Martin's Press. 


\section{Koustourakis et al. - Day High School Students}

Symeou, L. (2007). Cultural capital and family involvement in children's education: tales from two primary schools in Cyprus. British Journal of Sociology of Education, 28(4), 473-487. doi: 10.1080/01425690701369525

Tabachnick, B. G., \& Fidell, L. S. (2007). Using multivariate statistics (5th ed.). Boston, MA: Pearson.

Thanos, Th., \& Tolios, E. (2013). Educational-cultural practices of parents and social origin. Journal of Research in Education and Training, 6, 54-89. doi: 10.12681/jret.757

Thanos, Th., \& Tolios, E. (2015). Cultural practices of parents and social origin. In Th. B. Thanos (Ed.), The Sociology of Education in Greece. Selection of Research (pp. 185-211). Athens: Gutenberg.

Thompson, R. (2009). Social class and participation in further education: evidence from the Youth Cohort Study of England and Wales. British Journal of Sociology of Education, 30(1), 29-42. doi: $10.1080 / 01425690802514318$

Tolios, E., \& Thanos, Th. (2015). Cultural practices of parents and social origin. In Th. B. Thanos (Ed.), The Sociology of Education in Greece. Selection of Research (pp. 448-455). Athens: Gutenberg.

Vaara, E., \& Whittington, R. (2012). Strategy-as-practice: Taking social practices seriously. The Academy of Management Annals, 6(1), 285336. doi: 10.1080/19416520.2012.672039

Van de Werfhorst, H. G., \& Hofstede, S. (2007). Cultural capital or relative risk aversion? Two mechanisms for educational inequality compared. British Journal of Sociology, 58(3), 391-415. doi: 10.1111/j.14684446.2007.00157.x

Van de Werfhorst, H. G., Sullivan, A., \& Cheung, S. Y. (2003). Social class, ability and choice of subject in Secondary and Tertiary Education in Britain. British Educational Research Journal, 29(1), 41-62. doi: 10.1080/0141192032000057366

Vryonides, M. (2009). Applying Bourdieu's Concepts of Social and Cultural Capital in Educational Research in Greece and Cyprus. In K. Robson \& C. Sanders (Eds.), Quantifying Theory: Pierre Bourdieu (pp. 129140). Netherlands: Springer. 
Wacquant, L. (2008). Pierre Bourdieu. In R. Stones (Ed.), Key sociological thinkers (pp. 261-277). Houndmills, Basingstoke, Hampshire: Palgrave Macmillan.

Wacquant, L. (2011). Habitus as topic and tool: Reflections on becoming a prizefighter. Qualitative Research in Psychology, 8(1), 81-92. doi: 10.1080/14780887.2010.544176

Wakeling, P. (2005). La noblesse d' état anglaise? Social class and progression to postgraduate. British Journal of Sociology of Education, 26(4), 505-522. doi: 10.1080/01425690500200020

Waters, J., \& Brooks, R. (2010). Accidental achievers? International higher education, class reproduction and privilege in the experiences of UK students overseas. British Journal of Sociology of Education, 31(2), 217-228. doi: 10.1080/01425690903539164

Gerasimos S. Koustourakis is professor at the University of Patras, Greece.

Georgia Spiliopoulou is teaching assistant staff at the University of Patras, Greece.

Anna Asimaki is associate professor at the University of Patras, Greece.

Konstantinos Lavidas is teaching and research associate at the University of Patras, Greece.

Contact Address: koustourakis@upatras.gr 